\title{
The Role of Marae in Tertiary Education Institutions
}

To my knowledge, the first marae to be erected in a New Zealand University was Te Herenga Waka marae at Te Kawa a Māui at Victoria University of Wellington in 1986. This was followed by Waipapa marae at Auckland in 1988. It seems though that what were known as teachers' colleges in the past pre-dated universities in the establishment of marae within their institutions. An example is Te Kupenga o Te Mātauranga marae at Massey established in 1980. One may ask why this is the case? This should not be a surprise. Having been involved in Teacher Education (as a student and as an educator) early in my career, I experienced first hand the concerted drive by Māori teacher educators in the mid 1970s and the 1980s to establish marae so that teaching could occur based on Māori pedagogy, including delivering knowledge from a culturally specific environment.

I would like to recall a few of these people at this time. The late John Tāpiata in Palmerston North, the late George Marsden in Hamilton and the late Tahu Rankin in Auckland were among these people. They were highly motivated to build marae on their respective campuses, as they saw the huge benefits in using this cultural structure or facility as a powerful medium to transform attitudes and reaffirm the value of Māori knowledge to the generations of students that passed through teachers' colleges. Remember too that prior to 1987 the Treaty of Waitangi was not heralded as a prominent covenant of our past that teachers should recognise as part of the curriculum they are required to teach. Instead, it was embedded in what was referred to as multicultural education. This meant that marae were used as a means to conscientise ${ }^{1}$ Pākehā students to the Māori world view as a means of transforming their attitudes to being open to cultural difference and diversity; from embracing Te Tiriti o Waitangi to adapting to the needs of our Māori children in their

Professor Ka'ai is currently a Professor in Māori Innovation and Development at Auckland University. In 1996 she was appointed as the foundation Chair in the Department of Māori Studies at the University of Otago, thus being the first Māori woman professor of Māori Studies at a University. 
classrooms. Furthermore, these marae became bastions for Māori students of teacher education. They would naturally gather at the marae to rejuvenate their souls, to reaffirm their identity, often through kapa haka, to network as Māori in a pan-tribal context and to support each other in their studies. The marae was in fact a natural gathering place for Māori staff and students to engage with each other on many levels.

The University of Otago, where I spent eleven years, has no marae. The reason for this is simply that Ngāi Tahu is opposed to educational institutional marae. This was agreed to by that University in the establishment of a Memorandum of Understanding between Te Rūnanga o Ngāi Tahu and the University, signed in 2000. All five North Island universities have marae.

The focus of this essay is to explore the notion of the role of a marae in tertiary education institutions, from the experience of advocating for a new building for what was initially simply Māori Studies at Otago. This was not merely from the basis of growth and expansion of the programmes, but also by aligning this growth with a cultural argument for the type of space staff wanted and required to deliver their programmes more effectively. The process of educating the University and Ngāi Tahu to agree to the new complex (emphasising again that it could never be a marae) was an interesting one. But the important outcome to be noted today is that Te Tumu's argument was compelling enough to win favour with both parties. This was a huge victory. To get compliance with the iwi and an historically conservative university was indeed a watershed in Te Tumu's development. However, it took ten years for the University to finally complete the complex, which was delayed several years because of funding issues. The complex was completed by the beginning of 2006 with the official opening on 14 February 2006.

Against this background Māori Studies staff at the University of Otago determined the kind of purpose-built facility required after first examining several significant factors. These included:

1. The role and function of a marae in the traditional and contemporary Māori world.

2. The emergence of Māori Studies as an academic discipline within universities in Aotearoa/New Zealand. 
3. The demography of Māori staff and students within the academy ${ }^{2}$ and keeping a close eye on any demographic changes.

4. The motivation and strategic thinking behind the establishment of marae in other tertiary institutions, such as forcing institutional responsiveness to Māori within the academy, and the role of Indigenous academics in 'Indigenising the Academy'.

\section{Defining a marae and its function}

Mead locates the concept and idea of a marae within ancient Polynesia. However, as cultures evolve, he posits that so too has the concept of marae:

Formerly the marae was the clear space in front of the wharenui where certain ceremonies were conducted. The site of the marae was usually referred to as the pā. Williams (1971:

243) defines the $p \bar{a}$ as a 'stockade' or 'fortified place'. Notwithstanding his definition, 'pā' was the common term used to describe the place where the marae was located. Nowadays the word 'marae' encompasses the whole complex.... Today we use the word marae to describe the complex of the land, buildings and facilities as they exist today. ${ }^{3}$

Whereas marae were a common feature on New Zealand's rural landscape, Meade argues that this is not the case today.

There are marae in towns and the cities, at universities and polytechnics, at secondary schools and primary schools. Several churches have marae. This wide range of sites for marae suggest that the idea is accepted as being a very useful one and that the idea itself can be put into practice in a number of ways. It follows that marae do not look exactly the same: some are close to the ideal model of a marae while others have departed often considerably, from the ideal. But they are still called a marae. ${ }^{4}$ A marae is best described as:

a complex that includes a whare tipuna (ancestral house), wharekai (dining hall), wharepaku (ablution block) and surrounding lands. Some marae may also have a whare karakia (church), sports grounds and housing for kaumätua and families.... Traditionally all marae belonged to kinships groups, either a whānau, hapū or iwi. This remains the same 
today with the exception of some newer urban marae. A marae is built on the kinships group's land. The kinship group looks after the marae and each person has a role to play in the smooth running of the facility. ${ }^{5}$

The land on which the complex is built is an important factor in understanding the concept of the marae and its function, as it is linked with other cultural concepts such as tūrangawaewae (a place for the feet to stand) and identity and of course matemate-ā-one (condition or state that elicits certain cultural responses). While marae have been classified by some in two categories, including traditional and modern, the distinctions are largely between the physical layouts. Traditional marae have several separate buildings, whereas modern marae have mainly opted for one building with several parts that serve different functions. This adaptation has occurred largely for convenience sake.

\section{Te Tumu-School of Māori, Pacific \& Indigenous Studies: A Case Study}

The name for the School of Māori, Pacific \& Indigenous Studies at the University of Otago is Te Tumu. This name was adopted for the following reasons:

1. The word, or its cognate form, seems to be known throughout Polynesia with similar meanings, particularly in the Eastern Polynesian languages including Hawaiian, Tahitian, Mangaian, Rarotongan, Mangarevan and Marquesan. ${ }^{6}$ Thus the name is inclusive of Polynesia and the Pacific Islands.

2. The meaning of the word 'tumu' includes 'foundation, stake, pole, trunk, stump, origin, source', but it is often used in the phrase 'te tumu herenga waka', 'the post for tying up canoes'. 7 In a more figurative sense, the School could be likened to a place where Māori and Pacific Island students, researchers and staff had a base from which to interact with the rest of the University and the community, as well as a place to meet and congregate like canoes converging on a place after travelling from elsewhere. They arrived on their waka (canoe) and tied their canoe to Te Tumu for the length of their stay and then departed to other places, having filled their kete mātauranga (baskets of 
knowledge). As well as the idea of a stop-off place, the Māori name implies stability and permanency as well as being soundly placed in the land. This acknowledges the location of the School with its relationship to Te Wai Pounamu and Aotearoa and therefore the relationship with Ngāi Tahu, Ngāti Māmoe, Waitaha and all other iwi represented in our staff and student population.

3. The concept of the canoe has been reflected, not only in the design of the new parts of the building, but also in some of the names used for the various parts of the canoe, including the following:

\begin{tabular}{|c|c|c|}
\hline Name & Meaning & Room and Function \\
\hline $\begin{array}{l}\text { Te Ūranga } \\
\text { Waka }\end{array}$ & $\begin{array}{l}\text { The landing place of the } \\
\text { canoe }\end{array}$ & $\begin{array}{l}\text { The courtyard area to the west of } \\
\text { the building that leads to the } \\
\text { main entrance. }\end{array}$ \\
\hline Te Paparewa & The deck of a vessel & $\begin{array}{l}\text { The open area on the ground } \\
\text { floor for the performing arts }\end{array}$ \\
\hline Te Riu & The bilge or hull of a canoe & $\begin{array}{l}\text { The seminar/teaching room on } \\
\text { the ground floor under the } \\
\text { dining-room }\end{array}$ \\
\hline Te Pakokori & $\begin{array}{l}\text { The deck house - the small } \\
\text { house or cabin on a } \\
\text { double canoe of an ocean- } \\
\text { going canoe }\end{array}$ & $\begin{array}{l}\text { Seminar room on the ground } \\
\text { floor which is physically laid out } \\
\text { like a wharepuni with mattresses } \\
\text { and can be used for residential } \\
\text { wānanga }\end{array}$ \\
\hline Te Pākaiahi & $\begin{array}{l}\text { The fireplace made of clay } \\
\text { used on an ocean going } \\
\text { canoe }\end{array}$ & $\begin{array}{l}\text { Dining hall and kitchen area on } \\
\text { the first floor }\end{array}$ \\
\hline Te Urungi & $\begin{array}{l}\text { The steering paddle, } \\
\text { rudder }\end{array}$ & $\begin{array}{l}\text { Level } 2 \text { - Reception and } \\
\text { administration floor and the } \\
\text { Dean's Suite }\end{array}$ \\
\hline Te Rā & $\begin{array}{l}\text { The sail made of woven } \\
\text { flax and wood, symbolic of } \\
\text { weaving and carving }\end{array}$ & $\begin{array}{l}\text { The tenth floor where weaving } \\
\text { and carving will be taught }\end{array}$ \\
\hline
\end{tabular}

Other Māori names used for spaces in the Te Tumu section of the South Tower have a more functional meaning: 


\begin{tabular}{|c|c|c|}
\hline Name & Meaning & Room and Function \\
\hline $\begin{array}{l}\text { Wāhi } \\
\text { Horohoroi - } \\
\text { Tāne }\end{array}$ & Shower area - Male & Male shower \\
\hline $\begin{array}{l}\text { Wāhi } \\
\text { Horohoroi - } \\
\text { Wāhine }\end{array}$ & Shower area - Female & Female shower \\
\hline Te Wānanga & $\begin{array}{l}\text { Place of discussion and } \\
\text { instruction }\end{array}$ & Reference library/meeting room \\
\hline Kāuta & Cooking shed & Kitchen area \\
\hline Te Piringa & The place of refuge & Dean's meeting room \\
\hline $\begin{array}{l}\text { Te Tari } \\
\text { Whakaahua } \\
\text { /Kōmiringa } \\
\text { Reta }\end{array}$ & $\begin{array}{l}\text { Photocopy and printing } \\
\text { office/Letter sorting }\end{array}$ & $\begin{array}{l}\text { Photocopy and printing } \\
\text { office/Letter sorting room }\end{array}$ \\
\hline $\begin{array}{l}\text { Te Wāhanga } \\
\text { Reo }\end{array}$ & The language section & $\begin{array}{l}\text { The third level which housed the } \\
\text { language team and two seminar } \\
\text { rooms }\end{array}$ \\
\hline $\begin{array}{l}\text { Te Wāhanga } \\
\text { Ahurea }\end{array}$ & The culture section & $\begin{array}{l}\text { The fourth level which housed the } \\
\text { culture team, research } \\
\text { assistants, tutors and } \\
\text { postgraduate students }\end{array}$ \\
\hline $\begin{array}{l}\text { Ngā } \\
\text { Kaiwhakaako }\end{array}$ & The tutors & The tutors' room \\
\hline $\begin{array}{l}\text { Te Iringa } \\
\text { Kōrero }\end{array}$ & $\begin{array}{l}\text { The place where } \\
\text { discussion is heard }\end{array}$ & Seminar/teaching room \\
\hline Ngā Pia & $\begin{array}{l}\text { The first order of learners } \\
\text { in the tradition house of } \\
\text { learning }\end{array}$ & Postgraduate room \\
\hline Te Matapaki & The discussion place & Postgraduate discussion room \\
\hline Whatinga ahi & Fire escape & Fire escape \\
\hline $\begin{array}{l}\text { Wharepaku - } \\
\text { Tāne }\end{array}$ & Male Toilet & Male Toilet \\
\hline
\end{tabular}

Te Kaharoa, vol. 1, 2008, ISSN 1178-6035 


\begin{tabular}{|l|l|l|}
\hline Wharepaku - & Female Toilet & Female Toilet \\
Wāhine & Weaving area & Weaving area \\
Wāhi Whakairo & Carving area & Carving area \\
\hline
\end{tabular}

So what did the old facility look like and what did staff move into in $2006 ?$
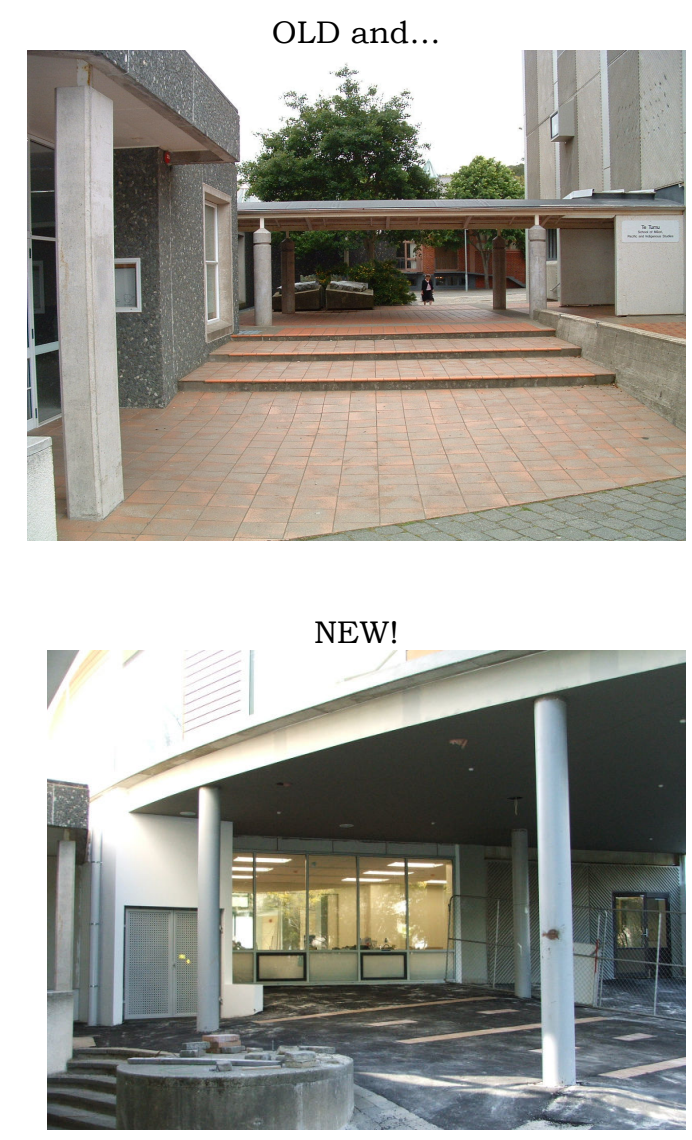

What was developed at Te Tumu was a multi-purpose complex designed around the concept of the name, Te Tumu.

Te Kaharoa, vol. 1, 2008, ISSN 1178-6035 
However, the complex provided an opportunity for Te Tumu staff to combine the role of academics as expected by the academy, while observing essential Māori cultural concepts and practices that originate from a Māori world view. This means staff were able to:

1. Implement Māori pedagogical practices to deliver our curriculum emanating from the traditional Māori concept of a marae, a bastion for Māori identity within the contemporary context and the cultural concept of wānanga.

2. Increase Māori visibility within the academy by putting Māori at the centre, not on the periphery, as the geographical location of Te Tumu is in the hub of the Humanities and almost in the centre of the University.

3. Provide a bastion (like the marae) where te reo me ngā tikanga Māori were observed and played out as an ordinary part of staff and students' daily lives within a working environment.

4. Be located together as staff of Te Tumu. ${ }^{8}$

But what of the benefits to Te Tumu staff? When asked this question the following sentiments were stated:

1. The 'space' was a strong symbolic cultural pedagogical tool to teach and learn using Māori specific forum such as wānanga.

2. The 'space' provided a strong sense of selfdetermination for staff to function within the academy in relation to advancing te reo me ngā tikanga Māori.

3. The 'space' provided a strong sense of power and control as opposed to feeling powerless, marginalised and of little value to the academy compared with other staff.

4. Staff felt a huge sense of achievement as teachers in that the 'space' was regarded as a teaching aid to ensure best teaching practice prevailed.

5. The 'space' rejuvenated the Māori teachers' souls and assisted in sustaining energy and focus in the light of the exhausting role we adopted as Māori academics of 'Indigenising the academy'. Therefore, it was the one space in the entire University where staff did not have to indigenise the academy. It was a space that enabled them to implement what bell hooks refers to as 'education as the practice of freedom'. 
6. The 'space' was where Māori knowledge was valid and so it was a complex that assumed a wairua similar to an inner sanctum, where the struggle for legitimacy within the academy was irrelevant. Therefore, the space offered a reprieve from the struggle for legitimacy beyond its walls.

7. The 'space' was an identity or cultural marker for the observance of, and respect for, a Māori world view by all who entered the complex. In other words, those who entered our hallowed halls were expected jump to Te Tumu's tune. ${ }^{9}$

8. The 'space' increased Te Tumu's visibility to the world. No longer would staff have to incur thoughts and feelings that they merely existed on the fringes of the academy. The 'space' is therefore a huge political statement to the University and its faculty and the community that Indigenous knowledge is a part of the academy as it has evolved in Aotearoa/New Zealand.

The new Te Tumu complex, which was our 'marae equivalent', gave further expression to the academic discipline and the status within the academy. Although Ngāi Tahu restricted Te Tumu from having pōhiri (rituals of encounter), including karanga (ceremonial call of welcome), and tangihanga (rites for the dead), the other functions of a marae were still available, especially in terms of the transmission of Indigenous knowledge and the advancement of te ao Māori at the University of Otago.

\section{Notes}

This is a term coined by Paulo Freire to describe the conscientisation of the mind as a means of liberating people from oppression (1996).

The term 'academy' is being used in this paper to refer to western educational institutions including universities.

S. M. Mead, Tikanga Mãori: Living by Māori Values, Wellington, 2003.

Op. cit.

R. R. Higgins, \& J. C. M. Moorfield, 'Te Marae' in T.M. Ka'ai, J.C. Moorfield, M.P.J. Reilly, S. Mosley. (eds), Ki te Whaiao - An Introduction to Māori Culture and Society, Auckland, 2004, 73.

6 E. Tregear, The Maori-Polynesian Comparative Dictionary. Wellington, 1891, p.551-552; M. K. Pukui, and S.H. Elbert, Hawaiian Dictionary, Honolulu, 1986. p. 182

Buse, J. and R. Taringa. 1995 Cook Islands Maori Dictionary. Canberra: Ministry of Ed., Gov. of the Cook Islands. p.524; Davies, J. 1991 A Tahitian and English Dictionary. Papeete: Editions Haere Po no Tahiti. p.288 
7 H. W. Williams, A Dictionary of the Maori Language. Wellington, 1971, p.453-454

8 When I first arrived at the University of Otago in 1996, staff were housed in five different geographical locations which meant that feelings of poor relation' haunted staff adding to their feelings of being on the periphery, invisible and of little value to the majority of the University faculty.

9 For example, no shoes were to be worn anywhere on the ground level of the complex because it was a performing arts space and it has a sprung floor. This equates to the rules in the dance studios in the School of Physical Education. Therefore, we invoked similar rules for Te Tumu.

Te Kaharoa, vol. 1, 2008, ISSN 1178-6035 